\author{
RICHARD N. COOPER \\ Yale University
}

\title{
Resource Needs Revisited
}

THE SHARP increase in raw materials prices in 1973-74 provoked strong concern over the scarcity of natural resources, particularly minerals. The last steep and general rise in raw materials prices, during the Korean War boom of 1950-51, also evoked great public concern about scarcities, about being cut off from leading sources of supply, and about governmental actions that might deal with these possibilities. After a series of hasty and somewhat panicky reports, President Harry S. Truman in January 1951 appointed the Paley Commission to study "the broader and longer range aspects of the nation's materials problem as distinct from the immediate defense needs." Its task was to "make an objective inquiry into all major aspects of the problem of assuring an adequate supply of production materials for our long-range needs," and specifically to study "the long-range requirements outlook." In June 1952, after the Korean commodity boom had subsided, the commission, under William S. Paley as chairman, published a thoughtful report, done with care, influenced but not dominated by the short-run scarcities of 1950 and $1951 .^{1}$ Its basic conclusions were that U.S. demands for materials would grow substantially and that although supplies were adequate at existing relative prices for many materials, for others they were not readily at hand and could be acquired only at increasing cost. It avoided the misconception of absolute shortage, and re-

1. Resources for Freedom, A Report to the President by the President's Materials Policy Commission, five volumes (1952). The quotations are from "The President's Letter," dated January 22, 1951, reprinted in vol. 1 of the report, p. iv. 
flected a clear understanding of upward-sloping supply schedules. It urged that steps be taken to develop more sources of some materials and to find substitutes for others that were prospectively scarce.

In meeting its charge, the commission projected U.S. demands for materials to $1975 .{ }^{2}$ Reviewing these projections can provide a rough report card on projections of "requirements" over a planning horizon as long as twenty-five years, and is particularly useful now in face of the talk about impending shortages and the need to "plan" for them. Indeed, a number of the alarums sounded recently are eerily reminiscent of those that spurred the creation of the Paley Commission.

The commission projected the growth of the U.S. economy from 1950 to 1975 , including the major components of final demand, and then related the consumption of specific raw materials to these aggregate projections, taking into account known trends in substitution. ${ }^{3}$ Relative prices were assumed to be unchanged.

This brief evaluation compares the projections of the Paley Commission for 1975 with actual consumption levels in 1972, a legitimate comparison since the report invites "readers [to] . . . view . . . use of the date 1975 as a shorthand means of denoting 'sometime in the 1970's. ", In fact, 1972 is superior to 1975 for purposes of comparison for several reasons apart from the availability of more complete data for the earlier year. Like 1950, 1972 was a year of economic recovery in the United States, with aggregate demand slack at the beginning and strong at the end. Furthermore, 1972 was not marked by panic buying and resulting sharp price increases, as was 1973, nor did it contain the distortions of the subsequent period of world recession. The comparison could be disturbed by the outbreak of speculative buying of materials in late 1950, but the commission presumably took that into account in making its projections. Most important, by 1972 actual expenditure in the U.S. economy exceeded the commission's projection in every category, usually by a substantial amount (see table 1).

This shortfall in the commission's projections, in fact, is the first major observation about them. The commission understated the growth in population and the labor force, and its projection of growth in real gross national

2. Much of the technical work on the projections was done by a promising young economist, Arnold C. Harberger.

3. The commission was concerned with water supplies and renewable resources as well, but the comparison here will be confined to mineral resources and energy.

4. Resources for Freedom, vol. 2, p. 112. 
Table 1. Comparison of the Paley Commission Projections of Growth in Selected Measures of the U.S. Economy, 1950-75, with Actual Growth, 1950-72

Percent

\begin{tabular}{|c|c|c|c|c|}
\hline \multirow[b]{2}{*}{ Measure } & \multicolumn{2}{|c|}{$\begin{array}{c}\text { Paley Commission } \\
\text { projections }\end{array}$} & \multicolumn{2}{|c|}{ Actual growth ${ }^{\mathbf{a}}$} \\
\hline & $1950-75$ & $\begin{array}{l}\text { Per } \\
\text { annum }\end{array}$ & $1950-72$ & $\begin{array}{c}\text { Per } \\
\text { annum }\end{array}$ \\
\hline Gross national product & 100 & 2.8 & 123 & 3.6 \\
\hline Gross private domestic investment & 40 & 1.3 & 80 & 2.8 \\
\hline Construction & 30 & 1.0 & 60 & 2.2 \\
\hline Producers' durables & 50 & 1.6 & 141 & 4.0 \\
\hline Consumers' durables & 40 & 1.3 & 202 & 5.0 \\
\hline Population & 27 & 1.0 & 37 & 1.4 \\
\hline
\end{tabular}

Sources: Resources for Freedom, A Report to the President by the President's Materials Policy Commission (1952), vol. 2, p. 116; Economic Report of the President, February 1975, table C-2, p. 250, and table C-23, p. 275.

a. GNP and components are computed from measures in 1958 dollars.

product implied a trend level for 1975 about 20 percent too low. Estimates of real expenditure on durable goods fell even further short of reality. Although fears of "underconsumption" in capitalist economies were beginning to recede by 1950, the notion of "saturation" with consumer goods was still strong. ${ }^{5}$ Moreover, to the extent that the Paley Commission's report is representative of expectations in 1951, the recent laments ${ }^{6}$ about low U.S. investment rates during the fifties and sixties, with their implications for low diffusion of new technology and sluggish growth of the economy, certainly cannot be justified. In fact, by 1972, gross investment had grown by 80 percent since 1950, twice the projected rate, and expenditure on producers' durables, which grew by 141 percent, almost tripled the expected rate.

Despite the substantial underestimation of growth in the U.S. economy, particularly in the demand for durables, the commission overestimated the

5. This notion is well illustrated by the following passage: "It is difficult to see how the projected economy would be willing to pay for more . . . [than] between 60 and 75 million telephones in . . 1975," compared to about 40 million in 1950 (Resources for Freedom, vol. 2, p. 115). In fact, the United States had 116 million telephones in 1972, and the number was still rising at the rate of about 5 million a year.

6. For a recent example, see Michael Boretsky, "Trends in U.S. Technology: A Political Economist's View," in American Scientist, vol. 63 (January-February 1975), pp. 70-82. 
consumption of most minerals. Table 2 compares the commission's projections for growth in consumption of twenty-four minerals (primary output only) from 1950 to " 1975 " with the actual increase in consumption from 1950 to 1972 . For seventeen of the twenty-four minerals shown, the commission's projections were overstatements, even though the economy outstripped expectations. In some respects the projections were not too bad: half of them fell within 20 percent of actual consumption. But the mean error was 46 percent, most errors were on the high side, and the average error on the high side was much bigger than the average error on the low side.

In one respect the commission was very much in tune with the anxieties of the seventies, however. Implicit in its projections of consumption of coal, petroleum, and natural gas is an expansion in total energy requirements (measured in Btu) of 97 percent. Actual growth was 112 percent, just slightly below what the commission would have predicted had it known the economy would grow as rapidly as it did.

What explains the general tendency toward failure of actual need for materials to match the estimates? One possibility is that the projected scarcities materialized, mineral prices rose (contrary to the projection's assumption of no change in relative price), and demand was consequently cut to match the limited supply. The percentage price changes shown in the last column of table 2, plotted in figure 1 against the projection errors in the next to last column, modestly support this explanation. The wholesale price index rose 45.6 percent between 1950 and 1972. Twelve of the twenty-four minerals experienced price increases in excess of 45 percent, and of those, nine involved projections in excess of actual consumption in 1972.

By the same token, the commission underestimated the demand for fertilizers (phosphate and potash), aluminum, and petroleum, all of which experienced below-average price increases. Thus, for thirteen of the twentyfour minerals, relative price movements help explain the error in projections, although the relationship is weak; and for eleven minerals projection errors were in the opposite direction from the effect of relative price movements on consumption.

Two other possible explanations come to mind: first, that improved secondary recovery of metals-as recommended by the Paley Commissionreduced the need for new primary production. Unfortunately, for all six nonferrous metals for which the commission projected scrap recovery for 1975 , actual recovery was below projections-sometimes by substantial 
Table 2. Comparison of the Paley Commission Projections of Growth in Consumption of Selected Minerals and Energy, 1950-75, with Actual Growth, 1950-72, and Average Annual Price Changes

Amounts in thousands of short tons except as noted; changes in percent

\begin{tabular}{|c|c|c|c|c|c|c|}
\hline \multirow[b]{2}{*}{ Mineral } & \multicolumn{3}{|c|}{ U.S. consumption } & \multirow{2}{*}{$\begin{array}{c}\text { Increase } \\
\text { projected } \\
\text { by Paley } \\
\text { Com- } \\
\text { mission, } \\
1950-75\end{array}$} & \multirow{2}{*}{$\begin{array}{l}\text { Percent } \\
\text { devia- } \\
\text { tion of } \\
\text { actual } \\
\text { from } \\
\text { projected }\end{array}$} & \multirow{2}{*}{$\begin{array}{c}\text { Price } \\
\text { change, } \\
1960-72^{\mathrm{b}}\end{array}$} \\
\hline & 1950 & 1972 & Change $^{\mathrm{a}}$ & & & \\
\hline \multicolumn{7}{|l|}{ Ferrous minerals } \\
\hline Pig iron & 64,943 & 89,140 & 37 & 54 & 12 & 76 \\
\hline Chromium & 980 & 1,140 & 16 & 100 & 72 & 15 \\
\hline Cobalt & 4 & 7 & 71 & 344 & 160 & 36 \\
\hline Manganese & 1,650 & 2,331 & 41 & 50 & 6 & -32 \\
\hline Molybdenum & 13 & 31 & 141 & 170 & 12 & 89 \\
\hline Nickel & 100 & 159 & 59 & 100 & 26 & 216 \\
\hline Tungsten & 3 & 7 & 114 & 150 & 17 & 44 \\
\hline \multicolumn{7}{|l|}{$\begin{array}{l}\text { Nonferrous metals } \\
\quad \text { (primary) }\end{array}$} \\
\hline Aluminum & 951 & 4,587 & 382 & 291 & -19 & 41 \\
\hline Antimony & 15 & 16 & 6 & 81 & 71 & 101 \\
\hline Copper & 1,447 & 1,901 & 31 & 43 & 9 & 139 \\
\hline Lead & 756 & 869 & 15 & 53 & 33 & 31 \\
\hline Magnesium & 18 & 104 & 473 & 1,845 & 239 & 69 \\
\hline \multicolumn{7}{|l|}{ Mercury } \\
\hline (thousands of flasks) & 49 & 53 & 8 & 25 & 16 & 169 \\
\hline \multicolumn{7}{|l|}{ Platinum } \\
\hline (millions of troy ounces) & 1 & 2 & 215 & 30 & -59 & 77 \\
\hline Tin & 71 & 54 & -25 & 18 & 57 & 86 \\
\hline Titanium & 363 & 694 & 91 & $324^{\circ}$ & 122 & 41 \\
\hline Zinc & 981 & 1,151 & 17 & 39 & 19 & 28 \\
\hline \multicolumn{7}{|l|}{ Nonmetallic minerals } \\
\hline Fluorspar & 426 & 1,352 & 217 & 187 & -9 & 87 \\
\hline Phosphate & 9,611 & 29,535 & 207 & 150 & -19 & 0 \\
\hline Potash & 2,486 & 8,279 & 233 & 150 & -25 & 11 \\
\hline Sulfur & 4,988 & 9,833 & 97 & 110 & 7 & -8 \\
\hline \multicolumn{7}{|l|}{ Energy fuels } \\
\hline Coal & 494,000 & 526,000 & 6 & 54 & 45 & 58 \\
\hline \multicolumn{7}{|l|}{ Petroleum } \\
\hline (millions of barrels) & 2,157 & 5,122 & 137 & 109 & -12 & 35 \\
\hline \multicolumn{7}{|l|}{ Natural gas } \\
\hline (billions of cubic feet) & 6,026 & 23,009 & 282 & 142 & -37 & 135 \\
\hline $\begin{array}{l}\text { Total energy fuels } \\
\text { (trillions of Btu) }\end{array}$ & 31,282 & 66,287 & 112 & 97 & -7 & $\cdots$ \\
\hline
\end{tabular}

Sources: U.S. Bureau of the Census, Statistical Abstract of the United States, 1974 (1974), "Mining and Mineral Products" chapter, and ibid., 1954 (1954); U.S. Bureau of Mines, Minerals Yearbook, 1972, vol. 1 (1974), ibid., 1954, vol. 1 (1958), and ibid., 1950 (1953); Resources for Freedom, vol. 1, p. 24, and vol. 2, p. 118; Survey of Current Business, vol. 30 (December 1950), vol. 52 (November 1972), vol. 55 (February 1975), "Current Business Statistics" section in each.

a. Calculated from unrounded data.

b. Calculated from annual average prices for 1950 and 1972, except for pig iron, copper, and lead, which are calculated from prices in effect in June 1950 and 1972. c. Includes cadmium. 
Figure 1. Relationship between Errors in Paley Commission Projections of U.S. Consumption of Selected Minerals in 1975, and Actual Price Changes, 1950-72

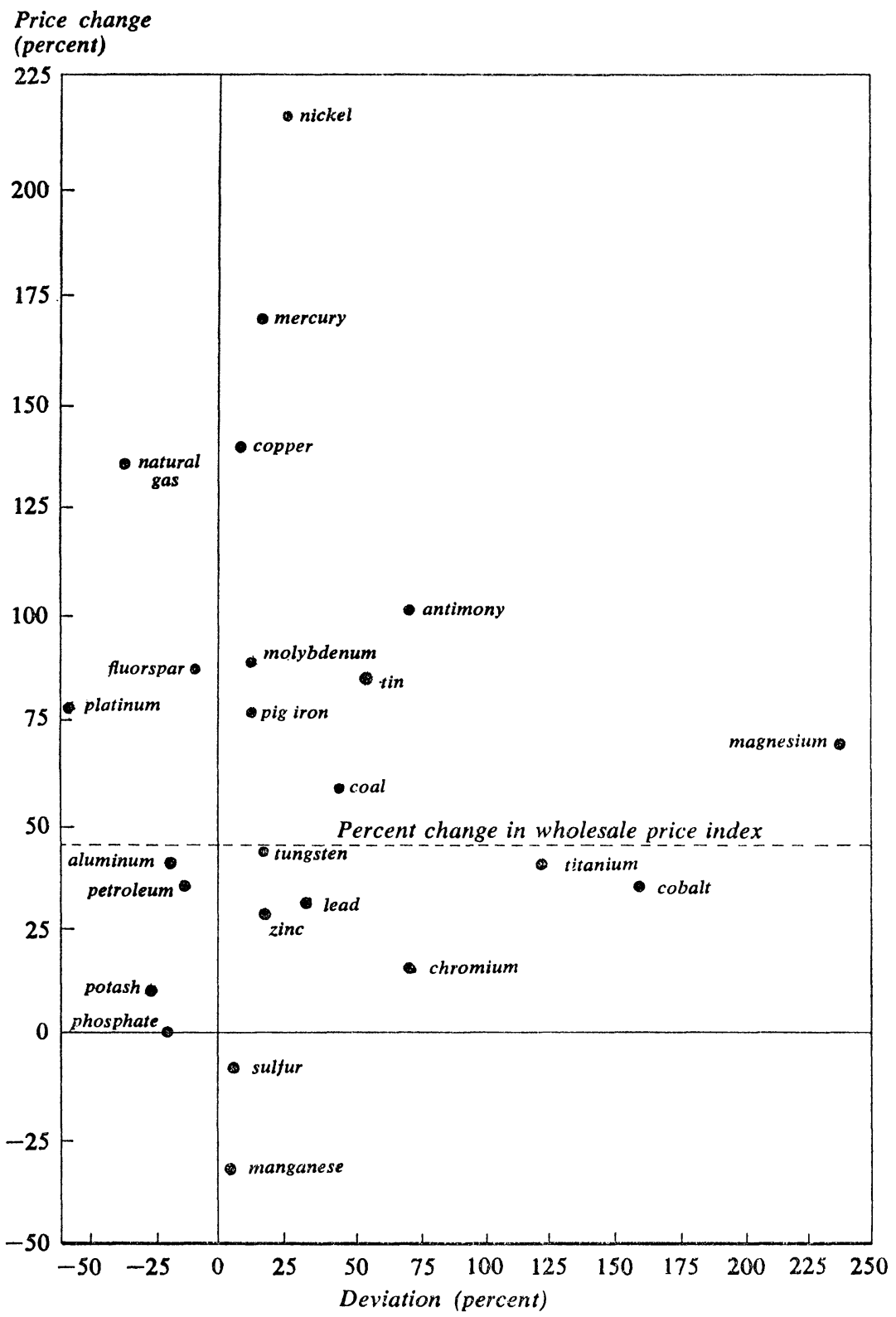

Source: Table 2. 
proportions. Indeed, secondary recovery of copper and tin was absolutely lower in 1972 than it was in 1950. This explanation, therefore, does not suffice.

Second, the enormous growth in imports of manufactured goods between 1950 and 1972-much greater than that in GNP-suggests that the U.S. economy was satisfying its resource needs through importation of finished goods rather than direct consumption of primary minerals. For example, the substantial increase in U.S. imports of steel products diminished U.S. need for pig iron. On the other hand, U.S. exports also expanded rapidly during this period. In terms of dollar values, U.S. exports increased about the same as did U.S. imports (both exclusive of the mineral products listed in table 2).

A rough calculation using the input-output tables for the United States suggests that the mineral contents of exports and import-competing goods (exclusive of direct trade in mineral products) are very similar, so that this explanation for the commission's underestimate of the economy's mineral needs also does not suffice. However, these tables are not well suited for analyzing the material content of various goods because they are based on shipments by U.S. producers and thus do not identify specific imported materials consumed in production. Further analysis on changes in indirect mineral content of U.S. trade is therefore required before the hypothesis can be rejected definitively.

While the Paley Commission generally overestimated the needs of the U.S. economy for mineral raw materials in the 1970s, it underestimated the needs of the noncommunist world economy as a whole, with the notable exceptions of tin, antimony, cobalt, and tungsten. The commission's broader projections were both less comprehensive and less meticulous than those for the United States; with this caveat, for eleven of the fifteen products it considered its estimates fell below actual world consumption (strictly, production) in 1972. This unexpected growth in mineral consumption was no doubt due to the historically unprecedented rate at which the world economy grew-very much faster than was thought likely in 1951. The upsurge in world demand for minerals may in turn explain the rise in relative prices of many minerals, and a consequent conservation in U.S. use.

Possibly only as a coincidence, for the one commodity-tin-covered by an international commodity agreement during this period, U.S. consumption declined absolutely and world demand fell well short of projections. In 
trying to stabilize tin prices, did the International Tin Council set them too high? Or were price factors swamped by new technologies of substitution?

The Paley Commission made many recommendations for dealing with the scarcities that it foresaw. Most concentrated on direct government actions and on government incentives to private industry to find and develop new sources of each mineral, partly in the United States but especially through direct investment abroad. A number of these incentives were adopted, and supplies, especially from abroad, no doubt responded to them. But the commission gave little encouragement to true conservation, and only general encouragement (rather than concrete recommendations) to the development of substitute materials. Thus, this is not one of those cases of failure to realize projections because recommendations to avoid their realization were successfully adopted. Rather, in ignoring technical changemeaning more efficient production as well as substitutes-beyond that known in 1950, the commission was ignoring the most important force for change in modern industrial economies. The ratio of material input to output fell faster than the commission allowed for, reflecting technical and managerial changes, many of which may well have been induced by the threat of scarcity. Such developments are certain to continue in the future; and the possibilities for secondary use of metals remain greatly underexploited. 